\title{
Histopatologi Hepar Tikus Wistar (Rattus norvegicus) Jantan setelah Pemberian Teh Kombucha Konsentrasi 100\% dengan Waktu Fermentasi yang Berbeda
}

\section{Liver Histopathology of Male Wistar Rats (Rattus norvegicus) after 100\% Concentration Kombucha's Tea Treatment with different days fermentation}

\author{
Agung Putra Nugraha ${ }^{1 *}$, Sri Isdadiyanto ${ }^{2}$, Silvana Tana ${ }^{2}$ \\ ${ }^{1)}$ Program Studi Biologi, Departemen Biologi, Fakultas Sains dan Matematika, Universitas Diponegoro \\ ${ }^{2)}$ Departemen Biologi, Fakultas Sains dan Matematika, Universitas Diponegoro \\ Jl. Prof. Soedarto, SH, Tembalang, Semarang \\ *Email : nugraha_jackers@yahoo.com
}

Diterima 29 Desember 2017 / Disetujui 26 Januari 2018

\begin{abstract}
ABSTRAK
Hepar berfungsi sebagai biotransformasi, penyimpanan nutrisi dan detoksifikasi racun yang datang melalui makanan dan minuman. Minuman fermentasi dapat mempengaruhi kondisi jaringan hepar dan bobot badan karena hasil dari metabolit sekunder adalah alkohol dan beberapa asam organik. Penelitian ini dilakukan untuk mengkaji dan menganalisis pengaruh perlakuan teh kombucha fermentasi 6 (P1), 9 (P2) dan 12 (P3) hari fermentasi konsentrasi $100 \%$ terhadap jaringan hepar, diameter hepatosit, bobot badan, konsumsi pakan dan minum. Penelitian ini menggunakan 16 ekor tikus Wistar jantan terdiri atas 4 perlakuan dan 4 kali ulangan. Perlakuan penelitian ini terdiri dari P0 : perlakuan kontrol; P1, P2 dan P3 berturut-turut adalah perlakuan teh kombucha fermentasi 6, 9 dan 12 hari konsentrasi 100\%. Penelitian ini menggunakan Rancangan Acak Lengkap (RAL). Variabel yang diukur pada penelitian ini adalah diameter hepatosit, bobot badan, konsumsi pakan dan minum pada hewan uji. Data yang diperoleh dianalisis menggunakan Analysis of Variance (ANOVA) pada taraf kepercayaan 95\% dan apabila terdapat perbedaan nyata, dilanjutkan uji Duncan. Hasil analisis data menunjukkan bahwa teh kombucha fermentasi 6, 9 dan 12 hari konsentrasi $100 \%$ tidak memiliki perbedaan nyata terhadap seluruh variabel. Histologi hepar terlihat normal dan tidak menunjukkan ciri-ciri kerusakan sel. Hal ini dapat disimpulkan bahwa teh kombucha dapat dikonsumsi aman oleh mammalia karena tidak menimbulkan kerusakan hepar pada hewan model penelitian.
\end{abstract}

Kata kunci : histopatolgi, hepar, teh kombucha, bobot badan, tikus wistar (Rattus norvegicus)

\section{ABSTRACT}

Liver served as biotransformation and storage of nutrients as well as detoxification of toxins that came through food and drink. Fermented drinks could affect secondary metabolic conditions such as organic acid and alcohol. This research was conducted to study and analyze the influence of kombucha fermentation 6 (P1), 9 (P2) and 12 (P3) days fermentation with 100\% concentration on hepatic tissue, hepatocyte diameter, body weight, feed and drink consumption. This study used 16 male Wistar rats consisted of 4 treatments and 4 repeat. The treatment of this study consisted of P0: control treatment; P1, P2 and P3 were treatment of kombucha fermented tea 6,9 and 12 days of $100 \%$ concentration respectively. This research used Completely Randomized Design (RAL). The variables measured in this study were hepatocyte diameter, body weight, feed and drink consumption in animal test. The data obtained were analyzed using Analysis of Variance (ANOVA) at 95\% confidence level. The result of data analysis showed that kombucha fermentation 6, 9 and 12 days of $100 \%$ concentration had no significant difference to all variables. Histology of the liver were not indicate the presence of tissue-damaged features such as chronic inflammation (cirrhosis). It could be concluded that tea kombucha was safe for consumption by mammalia because it was not affect liver damage of reserarch's animal model.

Keywords : histopathology, hepar, kombucha tea, weight, wistar rat (Rattus norvegicus) 


\section{PENDAHULUAN}

Hepar merupakan salah satu organ di dalam tubuh yang mempunyai peran penting sebagai penetral racun. Hepar bertanggung jawab atas biotransformasi zat-zat berbahaya menjadi zat-zat yang tidak berbahaya. Proses ini menyebabkan sel hepar mudah sekali mengalami kerusakan baik berupa kerusakan struktur sel maupun terjadi gangguan fungsi pada hepar (Aisyah, 2015). Selsel yang terdapat di hepar antara lain hepatosit dan sel makrofag yang disebut sebagai sel Kupffer dan sel Ito. Sel hepatosit berderet secara radier dalam lobulus hepar dan membentuk lapisan 1-2 sel serupa dengan susunan bata. Lempeng sel ini mengarah dari tepian lobulus ke pusatnya dan beranastomosis secara bebas membentuk struktur seperti labirin dan busa. Celah diantara lempenglempeng ini mengandung kapiler yang disebut sinusoid hepar. Aliran darah menuju ke vena sentralis dari portal triad, sedangkan aliran bile menuju ke portal triad dari dalam lobulus. Sel ito ialah sel yang berada di daerah disse berperan sebagai penimbun lipid (Junquiera et al, 2007).

Penelitian Afdina (2016) menjelaskan bahwa beberapa senyawa herbal yang masuk ke dalam tubuh akan mengalami proses absorbsi, distribusi, metabolisme dan ekskresi. Hepar merupakan organ utama metabolisme yang sering mengalami kerusakan karena senyawa itu sendiri atau penimbunan metabolit. Senyawa akan mengalami metabolisme di hepar dan akan terjadi perubahan struktur kimia yang dikatalisis oleh enzim yang dihasilkan oleh mikrosom sel hepatosit yang disebut biotransformasi. Senyawa obat atau herbal akan diubah menjadi metabolit yang biasanya kurang aktif dari obat asalnya. Proses metabolisme obat tidak selalu merupakan proses detoksikasi obat atau eliminasi persenyawaan tersebut, kadang-kadang terjadi transformasi obat menjadi senyawa intermediet yang reaktif dan toksik terhadap hepar. Cedera hepar akut akan menyebabkan perubahan metabolisme yang kemudian akan mengakibatkan perubahan struktur dan perubahan fungsi.

Teh kombucha merupakan minuman perpaduan rasa manis dan asam yang menyegarkan hasil dari fermentasi beberapa bakteri dan ragi membentuk "jamur teh" (Chen dan Liu, 2000). Teh kombucha disiapkan dengan menempatkan kultur kombucha (teh jamur) menjadi kaldu teh manis untuk proses fermentasi. Jika kultur kombucha dibudidayakan sesuai dengan resep standar dengan "black tea", dipermanis dengan sukrosa, ternyata substrat ini menjadi minuman yang disebut minuman teh jamur menyegarkan dengan nilai gizi yang tinggi dan berkhasiat (Loncar et al, 2000). Teh kombucha adalah nama umum yang diberikan untuk pertumbuhan simbiosis bakteri asam asetat dan spesies ragi osmofilik di membran jamur yang dibudidayakan dalam teh manis (Jarrell, 2000). Teh kombucha bukanlah sebuah "jamur" melainkan asosiasi ragi dan bakteri (Jayabalan et al, 2014).

Jayabalan et al. (2014) menyebutkan bahwa beberapa penelitian mengaitkan manfaat dari teh kombucha, salah satunya ialah sebagai hepatoprotector. Teh kombucha telah dipelajari hepatoprotektifnya terhadap berbagai polutan lingkungan pada model hewan dan sel line. Penelitian ini telah diuji untuk mengkaji hepatoprotektif teh kombucha (disiapkan dari teh hitam) terhadap parasetamol (Pauline et al., 2001), karbon tetra klorida (Murugesan et al, 2009), aflatoksin B1 (Jayabalan et al, 2010). Berbanding terbalik dengan Kusumah (2008) menjelaskan bahwa pemberian teh kombucha per oral terjadi perubahan struktur histologi sel hepar pada semua tingkat dosis yaitu dosis $0,26 \mathrm{ml} 2 \mathrm{x} /$ hari $0,52 \mathrm{ml}$ $2 \mathrm{x} /$ hari $0,39 \mathrm{ml} 2 \mathrm{x} /$ hari menghasilkan degenerasi parenkimatosa, degenerasi hidropik sampai dengan nekrosis. Berdasarkan latar belakang di atas, perlu dilakukan penelitian pemberian teh kombucha terhadap hewan uji tikus putih sebagai uji praklinis untuk mengetahui dampak yang sebenarnya terjadi pada hepar setelah perlakuan.

\section{METODE PENELITIAN}

Penelitian dilakukan di Laboratorium Biologi Struktur dan Fungsi Hewan, Departemen Biologi Fakultas Sains dan Matematika, Universitas Diponegoro Semarang, pada bulan Mei sampai Juli 2016. Menggunakan Tikus Wistar (Rattus norvegicus) jantan sebanyak 16 ekor umur 2 bulan, sedang untuk bahan perlakuan yaitu Teh 
kombucha kadar $100 \%$ yang difermentasi selama 6, 9 dan 12 hari pada suhu $25^{\circ} \mathrm{C}$ per oral dengan spuit injeksi ujung berkanul. Adapun alat-alat yang digunakan yaitu 20 kandang individu yang dilengkapi dengan tempat minum dan pakan, gelas ukur, timbangan digital dan alat diseksi.

Penelitian ini menggunakan Rancangan Acak Lengkap dengan 4 perlakuan dan 4 ulangan yaitu : $\mathrm{P} 0=$ kontrol, tanpa tambahan teh kombucha, $\mathrm{P} 1=$ air minum $+1,8 \mathrm{ml}$ teh kombucha kadar $100 \%$ pagi dan sore fermentasi 6 hari, $\mathrm{P} 2=$ air minum $+1,8 \mathrm{ml}$ teh kombucha kadar $100 \%$ pagi dan sore fermentasi 9 hari, $\mathrm{P} 3=$ air minum + $1,8 \mathrm{ml}$ teh kombucha kadar $100 \%$ pagi dan sore fermentasi 12 hari. Pakan dan minum diberikan secara ad libitum. Variabel penelitian terdiri dari variabel bebas dan variabel terikat sebagai berikut : Variabel bebas adalah perlakuan oral teh kombucha fermentasi 6, 9 dan 12 hari konsentrasi $100 \%$. Variabel terikat meliputi struktur histologi hepar, bobot badan, konsumsi pakan dan konsumsi minum. Gambaran struktur histologi hepar dianalisa secara deskriptif. Perhitungan diameter hepatosit dilakukan dengan cara memilih secara acak 5 hepatosit terdekat pada vena sentralis, kemudian dirata-rata. Setiap hepatosit dijumlahkan sisi terlebar + sisi tersempit, lalu dibagi 2 . Analisis data diameter hepatosit, bobot badan, konsumsi pakan dan minum akan dilakukan uji normalitas Shapiro-wilk (Oktaviana, 2013), pada taraf kepercayaan 95\% dilanjutkan uji ANOVA (Mattjik dan Sumertajaya, 2006) dan apabila terdapat beda nyata, dilanjutkan dengan uji Duncan. Seluruh data kuantitatif akan dianalisa menggunakan bantuan aplikasi SPSS 16 (Saputro, 2013).

\section{HASIL DAN PEMBAHASAN}

Hasil analisis terhadap diameter hepatosit, bobot badan, konsumsi pakan dan konsumsi minum tikus Wistar jantan pada perlakuan teh kombucha konsentrasi $100 \%$ dengan waktu fermentasi yang berbeda disajikan pada Tabel 1 . Teh kombucha konsentrasi $100 \%$ dengan waktu fermentasi 6, 9 dan 12 hari menunjukkan hasil yang tidak berbeda nyata. Diameter hepatosit menunjukkan hasil tidak berbeda nyata. Teh kombucha merupakan fermentasi yang dilakukan secara aerob, sehingga menghasilkan metabolit sekunder berupa alkohol (Loncar et al, 2000). Gambar 1. menunjukkan kondisi hepar kontrol pada perbesaran 100 kali (A) dan 200 kali (B). Lumen vena sentralis (VS) dan portal triad (PT) terlihat jelas pada gambar mikroskopis perbesaran 100 kali. Hepatosit (H) dan sinusoid (S) yang merupakan saluran antara portal triad dan vena sentralis terlihat dengan jelas pada perbesaran 200 kali. Pewarnaan hematoksilin-eosin mewarnai merah muda untuk sitoplasma dan biru tua untuk inti. Hepatosit dapat terlihat pada perbesaran 400 kali seperti pada Gambar C. Hepatosit pada tanda panah terlihat jelas inti bewarna biru tua dan berbentuk bulat. Struktur inti dapat dilihat untuk mengidentifikasi kerusakan sel.

Tabel 1. Hasil analisis rata-rata bobot badan, diameter hepatosit, konsumsi pakan dan konsumsi minum tikus Wistar setelah perlakuan teh kombucha konsentrasi $100 \%$ dengan waktu fermentasi yang berbeda

\begin{tabular}{lcccc}
\hline \multicolumn{1}{c}{ Variabel } & P0 & P1 & P2 & P3 \\
\hline $\begin{array}{l}\text { Diameter } \\
\text { Hepatosit }(\mu \mathrm{m})\end{array}$ & $12,96^{\mathrm{a}} \pm 2,76$ & $15,67^{\mathrm{a}} \pm 3,23$ & $15,45^{\mathrm{a}} \pm 2,29$ & $12,13^{\mathrm{a}} \pm 2,17$ \\
$\begin{array}{l}\text { Bobot badan }(\mathrm{g}) \\
\text { Konsumsi }\end{array}$ & $195,5^{\mathrm{a}} \pm 3,35$ & $196^{\mathrm{a}} \pm 2,45$ & $207,5^{\mathrm{a}} \pm 9,23$ & $209,5^{\mathrm{a}} \pm 2,22$ \\
$\begin{array}{l}\text { pakan }(\mathrm{g}) \\
\text { Konsumsi } \\
\text { minum }(\mathrm{ml})\end{array}$ & $14,92^{\mathrm{a}} \pm 1,15$ & $14,22^{\mathrm{a}} \pm 1,59$ & $14.31^{\mathrm{a}} \pm 2,57$ & $13,85^{\mathrm{a}} \pm 0,92$ \\
\hline
\end{tabular}

Keterangan : Angka dengan superskrip yang sama pada satu baris menunjukkan tidak berbeda nyata pada taraf kepercayaan $95 \%$. 
Price dan Lorraine (2006) menjelaskan bahwa metabolisme hepar dapat terganggu karena substansi toksik seperti alkohol. Hal ini akan berdampak pada mekanisme kerusakan sel hingga nekrosis. Chen and Liu (2000) menjelaskan bahwa pembuatan teh kombucha dilakukan dengan cara fermentasi aerob. Fermentasi ini dilakukan dengan melibatkan unsur $\mathrm{O}_{2}$ dalam proses metabolismenya. Ethanol ialah salah satu metabolit sekunder yang dihasilkan oleh proses fermentasi. Kandungan ethanol meningkat seiring berjalannya waktu dan menghasilkan kandungan tertinggi ethanol $5,5 \mathrm{~g} / \mathrm{L}$ atau $0,5 \%$ diikuti penurunan lambat kandungan ethanol di waktu berikutnya.
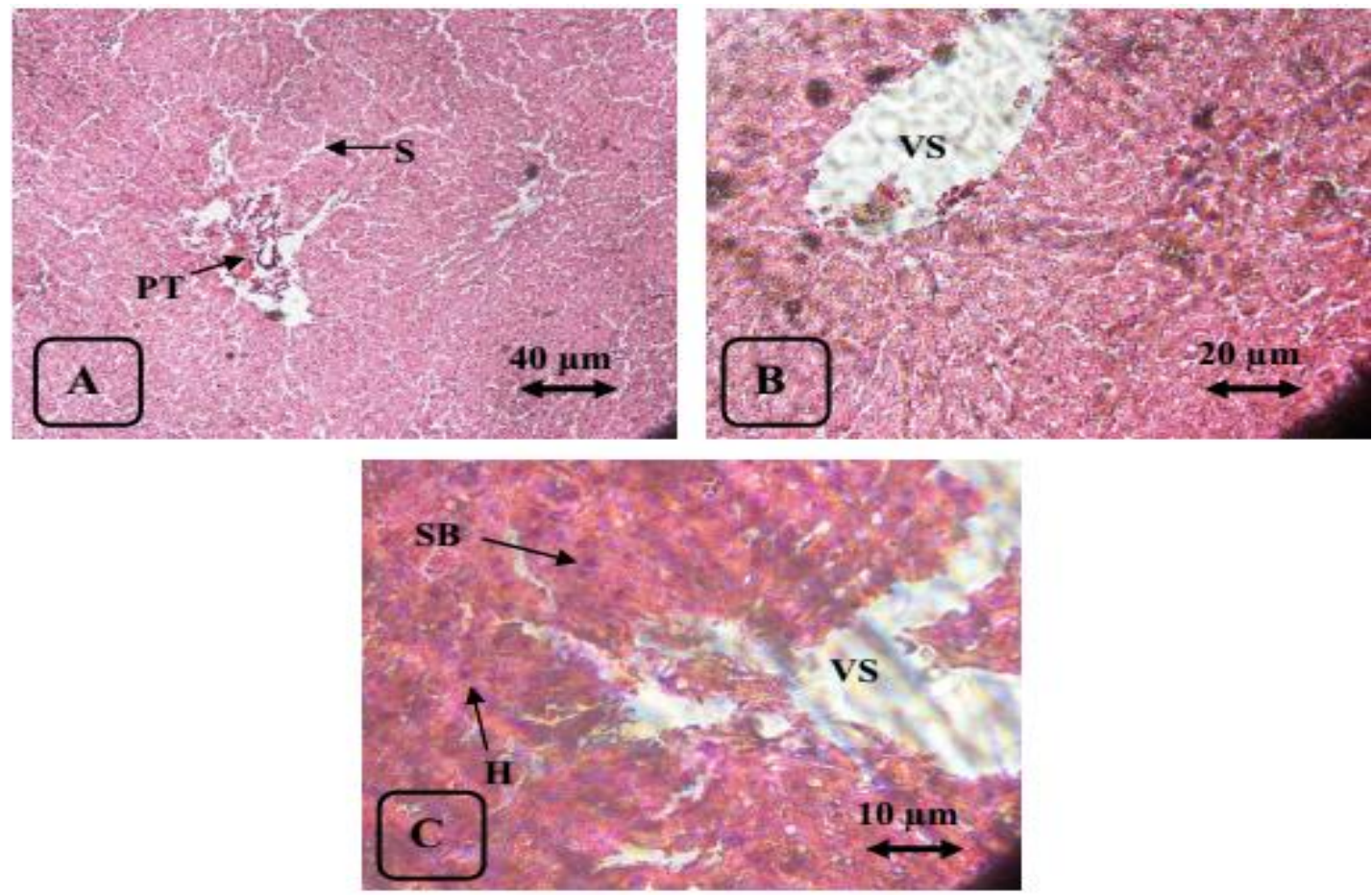

Gambar 1. Struktur mikroskopis hepar tikus Wistar pada kontrol, pewarnaan HE

Keterangan : A. Perbesaran 100x, B. Perbesaran 200x, C. Perbesaran 400x, VS : vena sentralis, H : hepatosit, PT : portal triad, S : sinusoid, SB : sel binukleat

Jayabalan et al. (2014) menjelaskan bahwa kandungan ethanol pada proses fermentasi 6 hari menghasilkan kandungan ethanol maksimal. Kemenperin RI (2017) menjelaskan bahwa standar minuman beralkohol di Indonesia untuk golongan A adalah sama dengan atau kurang dari 5\% mendapatkan izin untuk melakukan penjualan dan masih tergolong aman. Zakhari (2006) menjelaskan bahwa alkohol yang masuk ke dalam tubuh akan mengalami serangkaian proses biokimia. Alkohol yang dikomsumsi 90\%, diantaranya akan dimetabolisme oleh tubuh terutama hati oleh enzim alkohol dehirogenase (ADH) dan koenzim nikotinamid-adenindinokleotida (NAD) menjadi asetaldehid, kemudian oleh enzim aldehida dehidrogenase (ALDH) diubah menjadi asam asetat. Asam asetat dioksidasi menjadi $\mathrm{CO}_{2}$ dan $\mathrm{H}_{2} \mathrm{O}$. Piruvat, levulosa (fruktosa), gliseraldehida dan alanin akan mempercepat metabolism alkohol. Alkohol akan diubah menjadi asetaldehid, kemudian akan diubah menjadi asetat oleh aldehid dehidrogenase di dalam mitokondria. Pemakaian alkohol yang lama akan menimbulkan perubahan pada mitokondria, yang menyebabkan berkurangnya kapasitas untuk oksidasi lemak hingga menyebabkan terjadinya nekrosis.

Strukur histologi pada P1, P2 dan P3 tidak memiliki perbedaan nyata dengan kontrol. Preparat ketiga perlakuan dapat dilihat pada Gambar 2, 
Gambar 3 dan Gambar 4. Bobot badan, konsumsi pakan dan konsumsi minum juga tidak memiliki perbedaan yang nyata. Histogram bobot badan dapat dilihat pada Gambar 4.
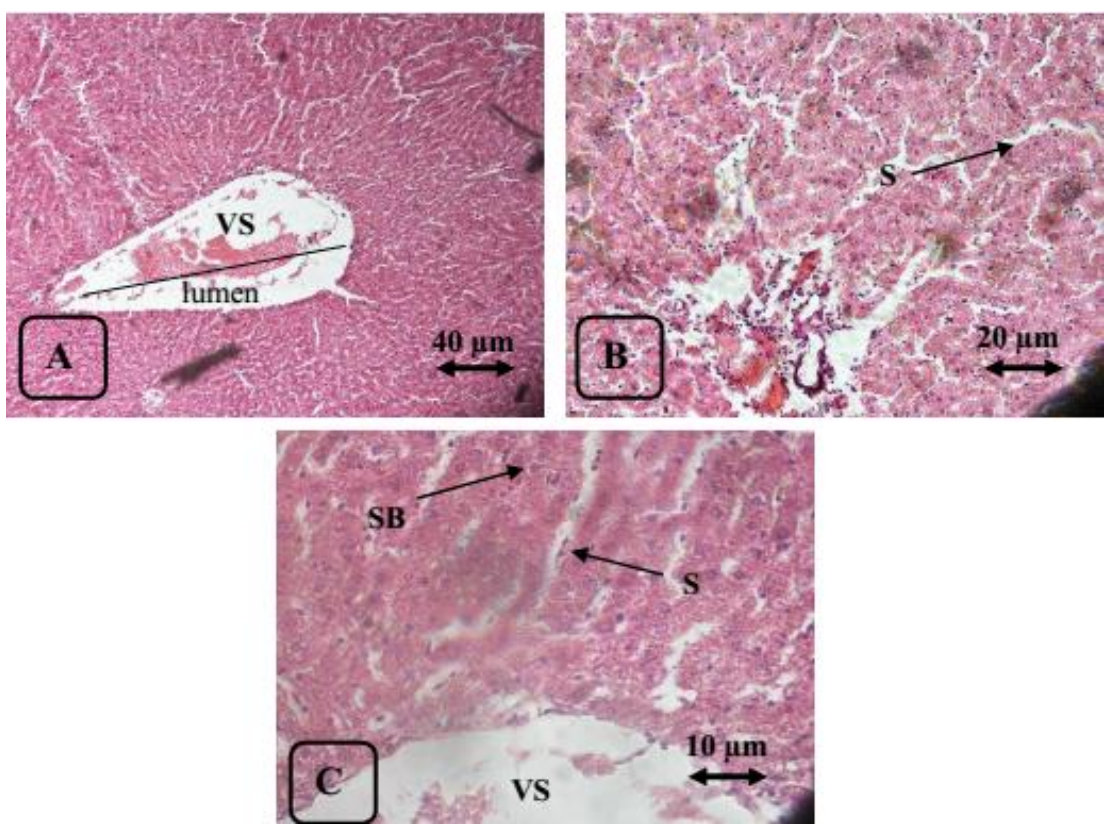

Gambar 2. Struktur mikroskopis hepar tikus Wistar pada perlakuan teh kombucha fermentasi 6 hari konsentrasi $100 \%$ (P1) pewarnaan HE

Keterangan : A. Perbesaran 100x, B. Perbesaran 200x, C. Perbesaran 400x, VS : vena sentralis, S : sinusoid, SB : sel binukleat
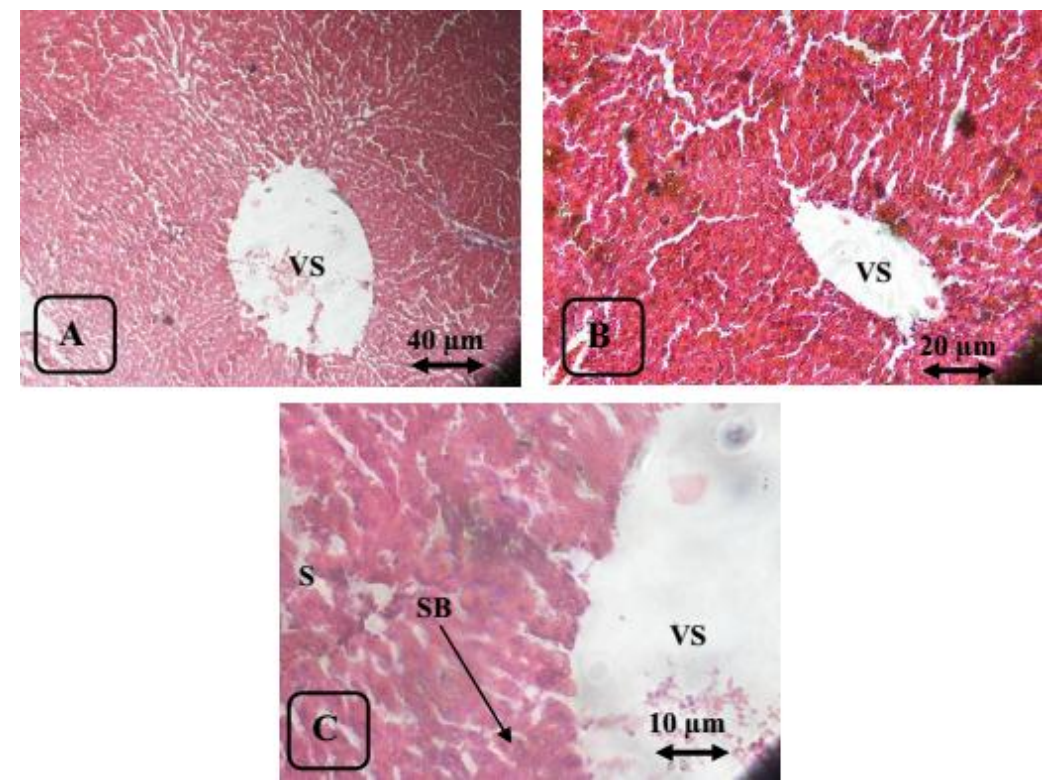

Gambar 3. Struktur mikroskopis hepar tikus Wistar pada perlakuan teh kombucha fermentasi 9 hari konsentrasi 100\% (P2) pewarnaan HE

Keterangan : A. Perbesaran 100x, B. Perbesaran 200x, C. Perbesaran 400x, VS : vena sentralis, S : sinusoid, SB : sel binukleat 

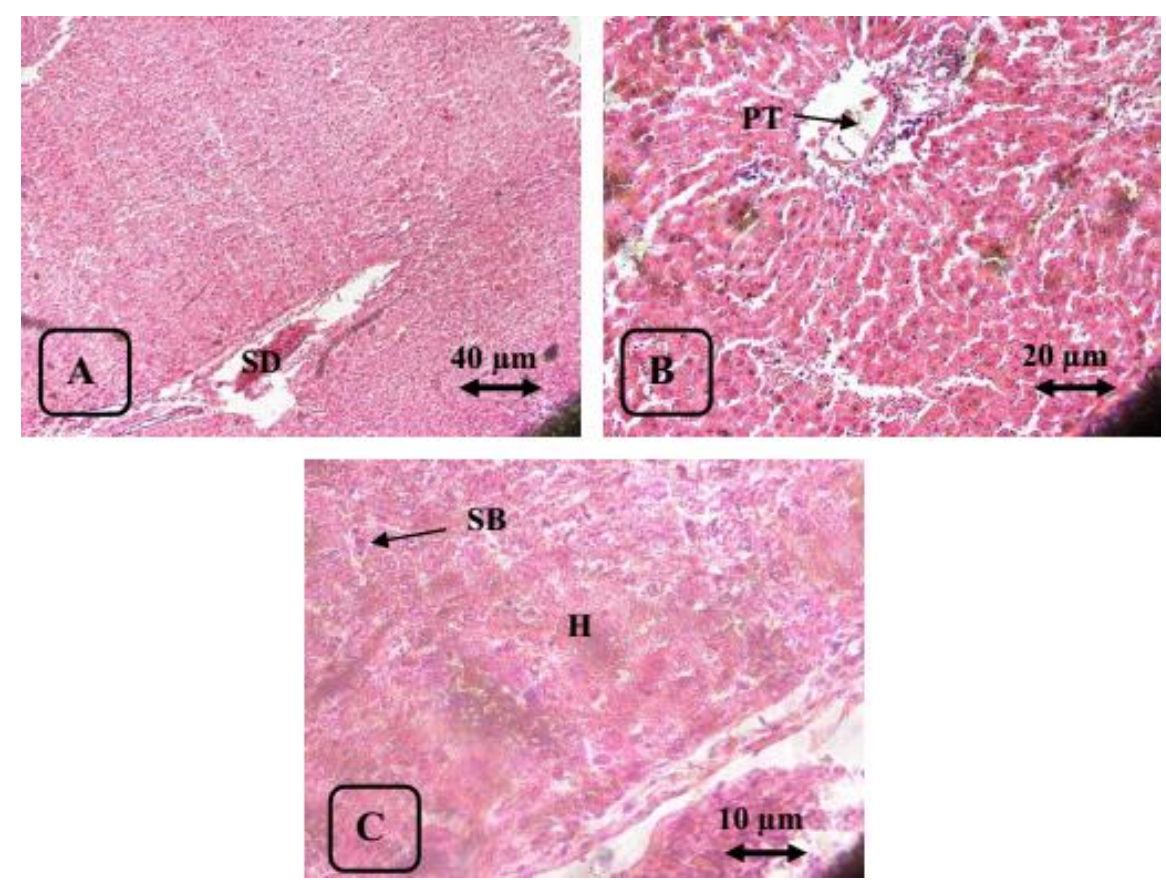

$\begin{array}{llcccccc}\text { Gambar 4. } & \begin{array}{l}\text { Struktur } \\ \text { kombucha }\end{array} & \text { mikroskopis } & \text { hepar } & \text { tikus } & \text { Wistar } & \text { pada } & \text { perlakuan teh } \\ & 12 & \text { hari } & \text { konsentrasi } & 100 \% & \text { (P3) pewarnaan }\end{array}$ HE (dokumentasi pribadi).

Keterangan : A. Perbesaran 100x, B. Perbesaran 200x, C. Perbesaran 400x, VS : vena sentralis, H : hepatosit, PT : portal triad, $\mathrm{S}$ : sinusoid, SB : sel binukleat

Preparat P1, P2 dan P3 tidak memiliki perbedaan dengan kontrol (P0), yaitu seluruh preparat tidak menunjukkan adanya perbedaan yang nyata terhadap perlakuan. Hal ini menunjukkan bahwa variabel bebas tidak mempengaruhi variabel terikat, artinya perlakuan tidak mempengaruhi diameter hepatosit, bobot badan, konsumsi minum dan konsumi pakan. Jayabalan et al. (2014) menjelaskan bahwa teh kombucha tidak dikategorikan sebagai substansi toksik.

Beberapa preparat menunjukkan adanya proses regenerasi sel dengan adanya sel binukleat atau sel yang memiliki dua inti yang saling berhimpitan. Anindyaputri (2017) menjelaskan bahwa proses regenerasi bisa terjadi pada hepatosit, sel parenkim hepar yang mampu menggandakan diri. Hepatosit bekerja mirip sel induk (sel punca) artinya hepatosit dapat menggandakan diri. Setelah hepatosit menggandakan diri, sel lainnya juga akan mengikuti dan memecah jadi beragam sel yang berbeda. Sel-sel baru tersebut lantas membentuk sebuah struktur baru, menyerupai lobulus hepar baru. Kemampuan ini hanya bisa dilakukan hepatosit jika kerusakan yang terjadi pada hepar ialah kerusakan ringan. Penelitian sebelumnya terdapat pendapat yang berbeda antara Jayabalan et al. (2014) dan Kusumah (2008). Jayabalan et al. (2014) menjelaskan bahwa teh kombucha dengan substrat teh hitam dapat memperbaiki kondisi hepar yang rusak karena kemampuan teh kombucha yang merupakan hepatoprotektif atau substansi yang dapat mendukung kerja hepar dengan cara mencegah hepar dari kerusakan selular. Kusumah (2008) menjelaskan bahwa teh kombucha pada dosis $0,26 \mathrm{ml}, 0,39 \mathrm{ml}$ dan $0,52 \mathrm{ml}$ pada hewan uji mencit BALB/c dapat menyebabkan terjadinya perubahan gambaran struktur histologis hepar berupa degenerasi parenkimatosa, degenerasi hidropik dan nekrosis.

Permana (2010) menyatakan bahwa rata-rata pemberian pakan harian untuk tikus putih Rattus norvegicus selama periode pertumbuhan dan reproduksi mendekati $15-20 \mathrm{~g}$ untuk jantan. Kebutuhan pakan bagi seekor tikus setiap harinya 
kurang lebih sebanyak 10\% dari bobot tubuhnya jika pakan tersebut berupa pakan kering dan dapat ditingkatkan sampai $15 \%$ dari bobot tubuhnya jika pakan yang dikonsumsi berupa pakan basah. Kondisi dimana pakan diberikan dalam jumlah yang sangat terbatas maka tikus dapat mengurangi konsumsi energinya, tetapi jika nafsu makan berlebih, tikus dapat meningkatkan penggantian energi.

Wolfenshon and Lloyd (2013) menyatakan bahwa kebutuhan minum tikus $10 \mathrm{ml} / 100 \mathrm{~g}$ berat badan. Hal ini membuktikan bahwa pemberian teh kombucha tidak memberikan pengaruh yang bermakna terhadap konsumsi minum tikus putih sehingga konsumsinya tetap normal. Anugrah (2005) menyatakan bahwa semakin lama waktu fermentasi teh kombucha maka semakin banyak kandungan asam-asam organik sehingga menurunnya palatabilitas. Muliani (2015) menjelaskan bahwa kadar teh kombucha yang semakin tinggi menyebabkan konsumsi minum berkurang, karena kadar teh kombucha yang semakin tinggi menyebabkan air minum terasa semakin asam sehingga akan mengurangi konsumsi minum.

Hasil penelitian dan pembahasan di atas menyimpulkan bahwa konsumsi pakan, konsumsi minum, bobot badan dan diameter sel hepatosit pada jaringan hepar tidak berbeda nyata, sehingga keempat variabel tersebut tidak dipengaruhi oleh ketiga perlakuan.

\section{KESIMPULAN}

Berdasarkan hasil penelitian, maka dapat disimpulkan bahwa pemberian $1,8 \mathrm{ml}$ teh kombucha fermentasi 6, 9, dan 12 hari konsentrasi $100 \%$ selama 35 hari tidak mempengaruhi diameter hepatosit hepar, bobot badan, konsumsi minum dan konsumsi pakan. Hal ini menunjukkan bahwa kombucha dapat dikonsumsi aman oleh mammalia karena tidak menimbulkan kerusakan hepar pada hewan model penelitian.

\section{DAFTAR PUSTAKA}

Afdina, M. 2016. Peran dan Fungsi Sel yang terdapat pada Organ Hepar.
Skripsi. Bandung. Sekolah Tinggi Farmasi Indonesia.

Aisyah, S., H. Budiman., D. Florenstina., dan D. Aliza. 2015. Efek pemberian Minyak Jelantah terhadap Gambaran Histopatologis Hati TikusPutih.Jurnal Media Veterinaria. 9(1) : 23.

Anindyaputri, I. 2017. Hepar Manusia:Regenerasi Sel.Jakarta.Hello Sehat Media Informasi Kesehatan.

Anugrah, S. T. 2005. Pengembangan Produk Kombucha Prebiotik Berbahan Baku Teh Hitam (Camelia Sinensis). Skripsi. Fakultas Teknologi Pertanian. Institut Pertanian Bogor.

Chen and Liu, 2000. Changes in major components of tea fungus metabolites during prolonged fermentation. Journal Applied Microbiology 89:834-9.

Janquiera, L. C., and J. Carnaeiro. 2002. Histologi Dasar. Alih Bahasa Adji Dharma. Penerbit Buku Kedokteran, Jakarta.

Jarrel, T., and J. W. Bennett. 2000. The Kombucha Consortia of Yeast and Bacteria. Journal Mycologist. 14:166-70.

Jayabalan, R., S. Baskaran., S. Marimuthu., K. Swaminathan., and S. E. Yun. 2010 . Effect of Kombucha on Aflatoxin B1 -Induced Acute Hepatotoxicity in Albinorats-Prophylactic and Curative Studies. Journal Applied Biology Chemical 53:407-16.

Jayabalan, R., V. Radomir., E. Malbasa., E. S. Loncar., S. Jasmina., S. Muthuswamy.2014.Comprehensiv Reviews in Food Science and Food Safety. Volume 13. A review of Kombucha Tea-Microbiology,Composition,

Fermentation, Benefical Effect, Toxicity, and Tea Fungus. Journal Institute of Food Technologists. $\quad$ Doi $\quad$ : $10.1111 / 1541$ 4337.12073. 
Kemenperin.go.id/artikel/8338/Standar kandungan minuman alkohol berlabel SNI. Diakeses 25 Desember 2017

Kusumah, A. 2008. Pengaruh Pemberian Teh Kombucha Per Oral Dengan Dosis BertingkatTerhadap Gambaran Histologi Hepar Mencit Balb/c. Skripsi. Semarang : Fakultas Kedokteran Universitas Diponegoro.

Loncar, E. S., S. E. Petrovic., R. V. Malbasa., and R. M. Verac. 2000. Biosynthesis of Glucuronic Acid by Means of Tea Fungus. Comprehensive Reviews in Food Science and Food Safety. Nahrung 44:138-9.

Mattjik, A. A., dan I. M. Sumertajaya. 2006. Perancangan Percobaan dengan Aplikasi SAS dan Minitab. Ed. Ke-3. IPB-Press. Bogor.

Muliani, H. 2015. Kadar Kolesterol Hepar Ayam Broiler setelah Pemberian Teh Kombucha. Buletin Anatomi dan Fisiologi Volume XXIII, Nomor 2.

Murugesan, G. S., M. Sathishkumar., R. Jayabalan., A. R. Binupriya., K. Swaminathan., and S. E. Yun. 2009. Hepatoprotectiveand curative properties of Kombucha tea against carbon tetrachloride -induced toxicity. Journal Microbiol Biotechnology 19:397 -402.

Oktaviana, 2013. Uji Normalitas Berdasarkan MetodeAndersonDarling. FMIPA UNY. Yogyakarta.
Pauline, T., P. Dipti., B. Anju., S. Kavimani., S. K. Sharma., A. K. Kain., S. K. Sarada., M. Sairam., G. Ilavazhagan., K. Devendra., and W. Selvamurthy. 2001. Studies on toxicity, anti-stress and hepato-protectivepropertiesof

Kombucha tea. Biomed Environtment Science 14:207-13.

Permana, Z. 2010. Konsumsi, Kecernaan dan Konsumsi Tikus Putih (Rattus norvegicus) yang Disuplementasi Biomineral Cairan Rumen dalam Ransum. Skripsi. Fakultas Peternakan. InstitutPertanianBogor.

Price, S. A., dan M. W. Lorraine., 2006. Patofisiologi : Konsep Klinis Proses-Proses Penyakit. Edisi 6. Volume 1. Jakarta : EGC.

Saputro, R. 2013. Statistik Terapan : Ilmu Kesehatan Masyarakat. Padang Stikes PerintisSumatera Barat.

Wolfenshon., and Lloyd. 2013. Handbook of Laboratory Animal Management and Welfare, 4th ed., Wiley-Blackwell : West Sussex, 234.

Zakhari, S. 2006. Overview: how is alcohol metabolized by the body ?. National Institute on Alcohol Abuse and Alcoholism (NIAAA) 5635, Fisher Lane. MSC 9304 Bethesda. 